\title{
The effect of iron supplements on pregnancy in rats given a low-zinc diet
}

\author{
BY SUSAN J. FAIRWEATHER-TAIT AND VIV PAYNE \\ AFRC Food Research Institute, Colney Lane, Norwich NR4 7UA
}

AND CHRISTINE M. WILLIAMS

North East Surrey College of Technology, Reigate Road, Ewell, Surrey KT17 3DS

\author{
(Received 2 March 1983 - Accepted 15 February 1984)
}

\begin{abstract}
1. Female Wistar rats were given an adequate-zinc $(60 \mu \mathrm{g} / \mathrm{g})$ or low-Zn $(7 \mu \mathrm{g} / \mathrm{g})$ diet for a minimum of 2 weeks and then mated. They were then either continued on the same diets $(+\mathrm{Zn}-\mathrm{Fe}$ or $-\mathrm{Zn}-\mathrm{Fe})$ or given similar diets supplemented with four times the normal level of iron $(+\mathrm{Zn}+\mathrm{Fe}$ or $-\mathrm{Zn}+\mathrm{Fe})$. The day before parturition they were killed and the fetuses removed and analysed.

2. There were no differences in numbers of fetuses or the number of resorption sites. In the absence of Fe supplementation, the mean fetal wet weight was significantly less $(P<0.05)$ in the low-Zn group but there was no effect of $\mathrm{Zn}$ in the two Fe-supplemented groups. The addition of Fe significantly decreased $(P<0 \cdot 05)$ the mean fetal wet weight in the adequate- $Z n$ groups but had no effect in the low-Zn groups. There were no differences in fetal dry weight, fat, protein or DNA content. Both Fe-supplemented groups produced fetuses of higher Fe concentration $(P<0.01)$, and mothers with higher bone Fe-concentration $(P<0.01)$ compared with the non-supplemented groups. The low-Zn groups produced fetuses of lower $\mathrm{Zn}$ concentration $(P<0.001)$ than the adequate- $\mathrm{Zn}$ groups but there was no effect on maternal bone $\mathrm{Zn}$ concentration.

3. It was concluded that Fe-supplements did not adversely affect fetal growth from mothers given a low- $\mathrm{Zn}$ diet, but the addition of $\mathrm{Zn}$ to the unsupplemented diet increased fetal wet weight. These findings were not accompanied by any other differences in fetal composition or dry weight, and do not therefore lend support to the suggestion of an $\mathrm{Fe}-\mathrm{Zn}$ interaction.
\end{abstract}

The adverse effect of severe zinc deficiency in the rat is well known (Hurley, 1969): the pups are small and severely malformed. Marginal $\mathrm{Zn}$ deficiency has also been reported to affect live birth weight (Williams et al. 1973) and it has been suggested by Meadows et al. (1981) that one of the factors causing mothers to give birth to small-for-gestational-age babies is a diet marginally deficient in $\mathrm{Zn}$. They have also speculated that iron supplements during pregnancy might exacerbate the situation since $\mathrm{Fe}$ is believed to reduce intestinal absorption of $\mathrm{Zn}$ in non-pregnant adults (Solomons \& Jacob, 1981). This study is an investigation into the effect of $\mathrm{Fe}$ supplements on pregnancy in rats given an adequate- or low- $\mathrm{Zn}$ diet.

\section{MATERIALS AND METHODS}

Forty mature female Wistar rats (weighing approximately $200 \mathrm{~g}$ ) were given a semi-synthetic control diet containing adequate $\mathrm{Zn}$ from added zinc carbonate $(60 \mu \mathrm{g} \mathrm{Zn/g})$ and forty were given the control diet with no added $\mathrm{Zn}(7 \mu \mathrm{g} \mathrm{Zn} / \mathrm{g})$ for 2 weeks. At the end of this period, they were mated overnight with adult male Wistar rats. The occurrence of mating was checked by looking for spermatozoa in vaginal smears the following morning. As soon as this was confirmed, the females were caged separately. Animals that had been on the control diet $(+\mathrm{Zn})$ were either maintained on the same diet $(+\mathrm{Zn}-\mathrm{Fe})$ or given a similar diet supplemented with $\mathrm{Fe}(+\mathrm{Zn}+\mathrm{Fe})$. Those that had been on the control diet low in $\mathrm{Zn}(-\mathrm{Zn})$ were either maintained on the same diet $(-\mathrm{Zn}-\mathrm{Fe})$ or given a similar diet supplemented with $\mathrm{Fe}(-\mathrm{Zn}+\mathrm{Fe})$ and food intakes were recorded. The compositions of the diets are described on p. 80. 
Table 1. Composition of control diet $(\mathrm{g} / \mathrm{kg})$

\begin{tabular}{llr}
\hline Starch & 335 \\
Sucrose & 335 \\
Casein & 150 \\
Mineral mix & 40 \\
& Vitamin mix & 20 \\
& Solka floc & 40 \\
& Maize oil & 80 \\
\hline
\end{tabular}

* Mineral mix (g/kg diet): $\mathrm{CaHPO}_{4} 13 \cdot 0, \mathrm{CaCO}_{3} 8 \cdot 2, \mathrm{KCl} 7 \cdot 03, \mathrm{Na}_{2} \mathrm{HPO}_{4} 7 \cdot 4, \mathrm{MgSO}_{4} \cdot \mathrm{H}_{2} \mathrm{O} 4 \cdot 0, \mathrm{MnSO}_{4} \cdot \mathrm{H}_{2} \mathrm{O}$ $0 \cdot 18, \mathrm{ZnCO}_{3} 0 \cdot 10, \mathrm{FeSO}_{4} \cdot 7 \mathrm{H}_{2} \mathrm{O} 0 \cdot 144, \mathrm{CuSO}_{4} 0 \cdot 015, \mathrm{KIO}_{3} 0 \cdot 001$.

$\dagger$ Vitamin mix (mg/kg diet): nicotinic acid 60, cyanocobalamin in mannitol 50, calcium-D-pantothenate 40 , thiamin hydrochloride 10 , riboflavin 10 , pyridoxine 10 , pteryolmonoglutamic acid 5, D-biotin 1 , menadione 1 , Rovimix E-25 (Roche) 300, Rovimix A-500 (Roche) 25, Rovimix A-500/D3 (Roche) 15, choline bitartrate 1800.

The morning on which the vaginal smears were positive was designated day 1 of pregnancy. On day 21 , i.e. the day before parturition, the animals were weighed and blood taken from the tail for haemoglobin ( $\mathrm{Hb}$ ) and packed cell volume (PCV) measurements. The animals were then killed under carbon dioxide and the fetuses and placentas were dissected out and any abnormalities noted. The litters of each animal were weighed, dried at $90^{\circ}$ for $24 \mathrm{~h}$, re-weighed and ground in a pestle and mortar to a fine powder. The number of implantation sites and resorption sites were recorded and checked against the number of corpora lutea. The tibia and fibula from the mothers' left hind-limbs were removed for $\mathrm{Zn}$ and $\mathrm{Fe}$ analysis. Portions of the fetal homogenate were analysed for fat, and the dried defatted material was then analysed for $\mathrm{Fe}$ and $\mathrm{Zn}$ by atomic absorption spectrophotometry (AAS) and DNA and protein.

\section{Diets}

The composition of the control diet given to group $+\mathrm{Zn}-\mathrm{Fe}$ is shown in Table 1. Group $+\mathrm{Zn}+\mathrm{Fe}$ was given the same diet with added $\mathrm{Fe}$ in the same proportions as $\mathrm{Fe}$ supplements normally given to pregnant women, i.e. four times the recommended daily allowance (US) National Research Council, 1974). This was achieved by adding a further $576 \mathrm{mg}$ ferrous sulphate to the $144 \mathrm{mg}$ already present in each $1 \mathrm{~kg}$ diet. Groups $-\mathrm{Zn}-\mathrm{Fe}$ and $-\mathrm{Zn}+\mathrm{Fe}$ were given a low- $Z n$ diet, which was achieved by omitting the zinc carbonate usually added to the mineral mix. The diet given to group $-\mathrm{Zn}+\mathrm{Fe}$ also had $\mathrm{Fe}$ added as in that of group $+\mathrm{Zn}+\mathrm{Fe}$.

\section{Fats}

Accurately-weighed dried samples were defatted in dichloromethane-methanol $(9: 1, \mathrm{v} / \mathrm{v})$ in Soxhlet thimbles on a Tecator Soxtec 1040 extraction unit. The fat was collected in a cup, the solvent evaporated and the weight of fat deducted from the weight of sample to give the dried defatted weight. The defatted sample was removed from the thimble and dried before further analyses.

\section{$D N A$}

The DNA in defatted fetal homogenate was extracted by the method of Hofert \& White (1968) and estimated colorimetrically with indole (Hubbard et al. 1970).

\section{Protein}

Subsamples of defatted fetal homogenate were analysed for protein by the method of Lowry et al. (1951). 
$\mathrm{Hb}$ and $\mathrm{PCV}$

$\mathrm{Hb}$ was determined on freely-flowing blood from the tail vein using an $\mathrm{AO}$ haemoglobinometer (American Optical Corporation, Buffalo, New York). PCV was measured using the microhaematocrit technique.

\section{$A A S$}

Samples for $\mathrm{Fe}$ and $\mathrm{Zn}$ analysis were oven-dried at $90^{\circ}$ and ground to a fine powder with a pestle and mortar or stainless-steel coffee grinder. Portions of dry powder were ashed at $480^{\circ}$ for $48 \mathrm{~h}$, the ash dissolved in warm concentrated hydrochloric acid, made up to a suitable volume with distilled water, and filtered. The solutions were analysed by flame spectrophotometry on a Varian AA6 AAS with background correction using appropriate standards.

\section{Statistical analysis}

As the number of young sharing the blood supply in the uterus in the later stages of gestation has a profound effect on their size at birth (as reviewed by Widdowson, 1968), it was felt that the inclusion of values from animals with very small or very large litters might bias the results and lead to incorrect conclusions. It was therefore decided that outliers would be removed by the procedure of Anscombe (1960). The mean number of fetuses and standard deviations for each group were calculated and any animal that fell more than three standard deviations outside the mean was excluded. Using this technique, four animals were rejected from the experiment, one with a large number of fetuses (group $+\mathrm{Zn}-\mathrm{Fe}$ ) and three with a small number of fetuses (one from group $+\mathrm{Zn}+\mathrm{Fe}$ and two from group $-\mathrm{Zn}-\mathrm{Fe}$ ). Differences among the four group means were tested using the $F$ test modified for heterogeneous variance (Snedecor, 1957b). Tests for specific effects of $\mathrm{Fe}$ in the adequate- $\mathrm{Zn}$ or low- $\mathrm{Zn}$ groups, and $\mathrm{Zn}$ in the normal-Fe groups were carried out, using a modification of the $t$ test (Snedecor, 1957a) with the aid of the BMDP computer program (University of California, 1981). The influence of period of time on the $\mathrm{Zn}$-deficient diet on fetal $\mathrm{Zn}$ and bone $\mathrm{Zn}$ was examined, using the Spearman rank correlation test (Siegel, 1956).

\section{RESULTS}

The $\mathrm{Zn}$ and $\mathrm{Fe}$ contents $(\mu \mathrm{g} / \mathrm{g})$ of the diets given to the four groups were as follows: group $+\mathrm{Zn}-\mathrm{Fe}: \mathrm{Zn} 59 \cdot 6, \mathrm{Fe}$ 36·3; group + $\mathrm{Zn}+\mathrm{Fe}: \mathrm{Zn} 57 \cdot 6, \mathrm{Fe} 161 \cdot 5$; group $-\mathrm{Zn}-\mathrm{Fe}: \mathrm{Zn}$ $6 \cdot 8$, Fe 35.1; group $-\mathrm{Zn}+\mathrm{Fe}: \mathrm{Zn} 6.9, \mathrm{Fe} 171 \cdot 5$. It was not possible to mate all the animals at the same time and mating occurred sequentially over a period of $9 \mathrm{~d}$. Thus, the period of time on the $\mathrm{Zn}$-deficient diet varied between 14 and $23 \mathrm{~d}$ before the rats were made pregnant. There was no correlation, however, between period of time on the $\mathrm{Zn}$-deficient diet and fetal $\mathrm{Zn}$ or maternal bone $\mathrm{Zn}$. It was therefore concluded that this difference would not prejudice the results, particularly as the animals were randomly allocated to groups.

Mean daily food intakes, from 7-d periods, are given in Table 2. The unsupplemented low-Zn group ate slightly less in the third trimester $(P<0.05)$. Weight gain during pregnancy is shown in Fig. 1. During the third trimester, the mothers in the $-\mathrm{Zn}-\mathrm{Fe}$ group gained less than the $-\mathrm{Zn}+\mathrm{Fe}$ group $(P<0.05)$. Weight gain in each trimester was positively correlated with food intake $(P<0.001)$ in all groups.

The maternal $\mathrm{Hb}$ and PCV values are shown in Table 3 . There were no significant differences between the groups. There were no differences in maternal tibia and fibula dry weights, and the bone $\mathrm{Zn}$ and $\mathrm{Fe}$ values are shown in Table 4. The Fe concentration of 
Table 2. Mean daily food intake $(g / d)$ in each trimester of pregnancy in rats given diets ranging in zinc content, with or without iron supplements

(Mean values with their standard errors)

\begin{tabular}{|c|c|c|c|c|c|c|c|}
\hline \multirow[b]{2}{*}{ Group } & \multirow[b]{2}{*}{$n$} & \multicolumn{2}{|c|}{ Ist Trimester } & \multicolumn{2}{|c|}{ 2nd Trimester } & \multicolumn{2}{|c|}{ 3rd Trimester } \\
\hline & & Mean & SE & Mean & SE & Mean & $\mathrm{SE}$ \\
\hline$+\mathrm{Zn}-\mathrm{Fe}$ & 10 & $20 \cdot 3$ & 1.4 & 21.9 & $1 \cdot 2$ & $20 \cdot 2$ & $1 \cdot 1$ \\
\hline$+\mathrm{Zn}+\mathrm{Fe}$ & 11 & $20 \cdot 2$ & 0.7 & $22 \cdot 1$ & 0.7 & $20 \cdot 3$ & 0.8 \\
\hline$-\mathrm{Zn}-\mathrm{Fe}$ & 14 & $19 \cdot 2$ & 0.8 & $21 \cdot 7$ & 0.9 & $18 \cdot 3^{a}$ & 0.8 \\
\hline$-\mathrm{Zn}+\mathrm{Fe}$ & 16 & $20 \cdot 1$ & 0.8 & $22 \cdot 8$ & 0.9 & $21 \cdot 3$ & $1 \cdot 2$ \\
\hline
\end{tabular}

$+\mathrm{Zn}, \mathrm{Zn}$-adequate; $-\mathrm{Zn}$, low-Zn; + Fe, Fe-supplemented; - Fe, unsupplemented.

$a-\mathrm{Zn}-\mathrm{Fe}<-\mathrm{Zn}+\mathrm{Fe}(P<0 \cdot 05)$.

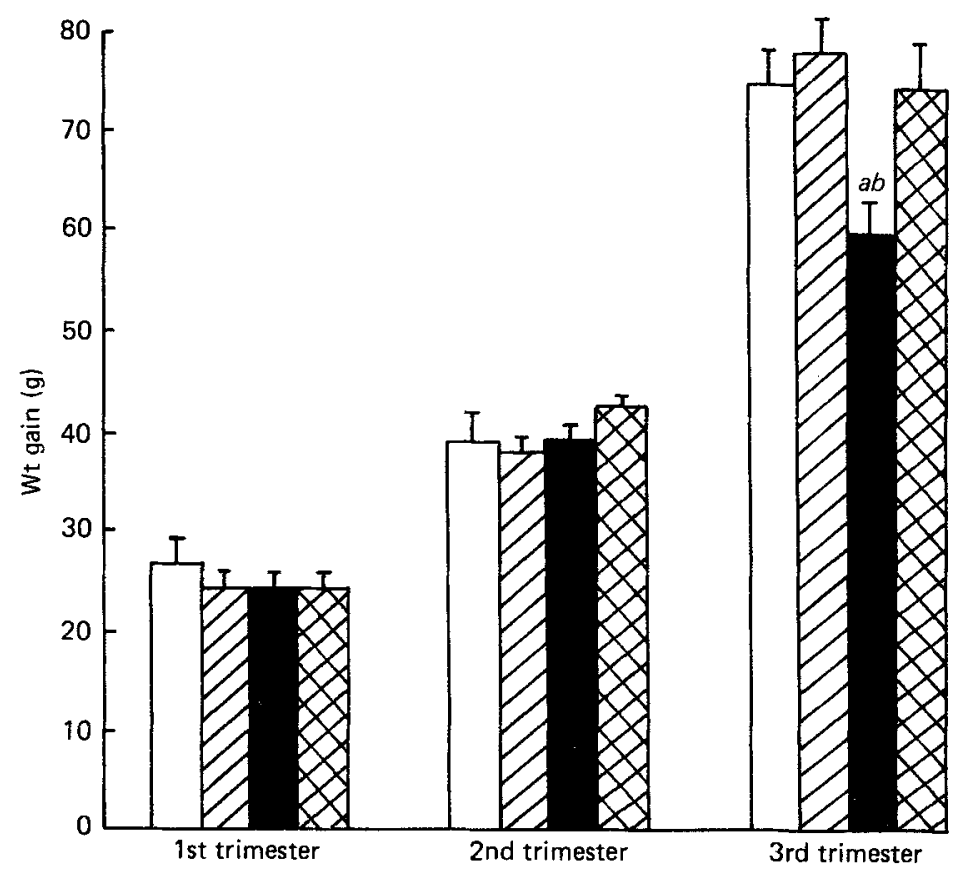

Fig. 1. Weight gain during each trimester of pregnancy in rats given ( $\square$ ), zinc-adequate control diet

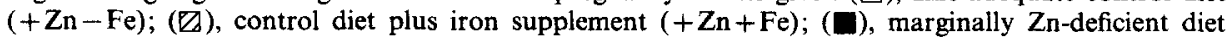
$(-\mathrm{Zn}-\mathrm{Fe}) ;(\otimes)$, marginally $\mathrm{Zn}$-deficient diet plus Fe supplement $(-\mathrm{Zn}+\mathrm{Fe})$. For details of diets, see p. 80 and Table 1. Values are means, with their standard errors represented by vertical bars. ${ }^{a}-\mathrm{Zn}-\mathrm{Fe}<-\mathrm{Zn}+\mathrm{Fe}(P<0.05) .^{b}-\mathrm{Zn}-\mathrm{Fe}<+\mathrm{Zn}-\mathrm{Fe}(P<0.05)$.

dried bone was higher in both the adequate- $\operatorname{Zn}(P<0.05)$ and low- $\operatorname{Zn}(P<0.01)$ Fe-supplemented groups. There were no differences in bone $\mathrm{Zn}$ concentrations although there was a trend towards lower levels in the low- $\mathrm{Zn}$ groups.

The mean number of resorption sites did not differ between the groups. The number of fetuses for each group, mean wet and dry fetal weights and fat content, are shown in Table 5. There were no differences in numbers of fetuses, dry weight or fat content. In the adequate- $\mathrm{Zn}$ groups, the addition of $\mathrm{Fe}$ significantly decreased fetal wet weight $(P<0.05)$, 
Table 3. Maternal haemoglobin $(\mathrm{Hb})$ and packed cell volume (PCV) on day 21 of pregnancy in groups of rats given diets ranging in zinc content, with or without iron supplements (Mean values with their standard errors)

\begin{tabular}{|c|c|c|c|c|c|}
\hline \multirow[b]{2}{*}{ Group } & \multirow[b]{2}{*}{$n$} & \multicolumn{2}{|c|}{$\mathrm{Hb}(\mathrm{g} / \mathrm{l})$} & \multicolumn{2}{|c|}{$\operatorname{PCV}(\%)$} \\
\hline & & Mean & $\mathbf{S E}$ & Mean & SE \\
\hline $\begin{array}{l}+\mathrm{Zn}-\mathrm{Fe} \\
+\mathrm{Zn}+\mathrm{Fe} \\
-\mathrm{Zn}-\mathrm{Fe} \\
-\mathrm{Zn}+\mathrm{Fe}\end{array}$ & $\begin{array}{l}10 \\
11 \\
14 \\
16\end{array}$ & $\begin{array}{l}11 \cdot 8 \\
12 \cdot 4 \\
12 \cdot 4 \\
12 \cdot 9\end{array}$ & $\begin{array}{l}0.2 \\
0.2 \\
0.3 \\
0.2\end{array}$ & $\begin{array}{l}33 \cdot 4 \\
35 \cdot 1 \\
35 \cdot 7 \\
36 \cdot 8\end{array}$ & $\begin{array}{l}0.8 \\
0.9 \\
0.5 \\
0.6\end{array}$ \\
\hline
\end{tabular}

$+\mathrm{Zn}, \mathrm{Zn}$-adequate; $-\mathrm{Zn}$, low-Zn; + Fe, Fe-supplemented; - Fe, unsupplemented.

Table 4. Maternal bone (tibia and fibula) zinc and iron on day 21 of pregnancy in groups of rats given diets varying in $\mathrm{Zn}$ content, with or without Fe supplements

(Mean values with their standard errors)

\begin{tabular}{|c|c|c|c|c|c|}
\hline \multirow[b]{2}{*}{ Group } & \multirow[b]{2}{*}{$n$} & \multicolumn{2}{|c|}{$\mathrm{Zn}(\mu \mathrm{g} / \mathrm{g}$ dried bone $)$} & \multicolumn{2}{|c|}{$\mathrm{Fe}(\mu \mathrm{g} / \mathrm{g}$ dried bone $)$} \\
\hline & & Mean & $\mathbf{S E}$ & Mean & $\mathbf{S E}$ \\
\hline$+\mathbf{Z n}_{\mathbf{n}}-\mathrm{Fe}$ & 10 & $303 \cdot 0$ & $33 \cdot 2$ & $38 \cdot 4$ & $1 \cdot 7$ \\
\hline$+\mathrm{Zn}-\mathrm{Fe}$ & 11 & $297 \cdot 3$ & $26 \cdot 4$ & $45 \cdot 6^{a}$ & $2 \cdot 7$ \\
\hline$-\mathrm{Zn}-\mathrm{Fe}$ & 14 & $274 \cdot 1$ & $28 \cdot 1$ & $37 \cdot 7$ & $1 \cdot 5$ \\
\hline$-\mathrm{Zn}+\mathrm{Fe}$ & 16 & $237 \cdot 1$ & $24 \cdot 4$ & $46 \cdot 9^{b}$ & $2 \cdot 4$ \\
\hline
\end{tabular}

$+\mathrm{Zn}, \mathrm{Zn-adequate} ;-\mathrm{Zn}$, low-Zn; + Fe, Fe-supplemented; - Fe, unsupplemented.

$a+\mathrm{Zn}+\mathrm{Fe}>+\mathrm{Zn}-\mathrm{Fe}(P<0.05)$.

$-\mathrm{Zn}+\mathrm{Fe}>-\mathrm{Zn}-\mathrm{Fe}(P<0.01)$.

Table 5. Number of fetuses per litter, mean wet and dry fetal weights $(\mathrm{g})$ and fat content $(\mathrm{g} / \mathrm{kg}$ dry weight) on day 21 of pregnancy in groups of rats given diets varying in zinc content, with or without iron supplements

(Mean values with their standard errors)

\begin{tabular}{|c|c|c|c|c|c|c|c|c|c|}
\hline \multirow[b]{2}{*}{ Group } & \multirow[b]{2}{*}{$n$} & \multicolumn{2}{|c|}{ Fetuses } & \multicolumn{2}{|c|}{ Wet wt } & \multicolumn{2}{|c|}{ Dry wt } & \multicolumn{2}{|c|}{ Fat } \\
\hline & & Mean & $\mathrm{SE}$ & Mean & SE & Mean & $\mathbf{S E}$ & Mean & $\mathrm{SE}$ \\
\hline$+\mathrm{Zn}-\mathrm{Fe}$ & 10 & $14 \cdot 1$ & 0.3 & $4 \cdot 84^{a b}$ & 0.11 & 0.64 & 0.05 & 94.6 & $4 \cdot 8$ \\
\hline$+\mathrm{Zn}+\mathrm{Fe}$ & 11 & $15 \cdot 4$ & 0.5 & $4 \cdot 51$ & 0.05 & 0.61 & 0.06 & $91 \cdot 0$ & $2 \cdot 8$ \\
\hline$-\mathrm{Zn}-\mathrm{Fe}$ & 14 & $14 \cdot 5$ & 0.7 & 4.49 & 0.08 & 0.60 & 0.05 & 102.4 & $3 \cdot 5$ \\
\hline$-\mathrm{Zn}+\mathrm{Fe}$ & 16 & $13 \cdot 9$ & 0.7 & $4 \cdot 67$ & 0.11 & 0.64 & 0.08 & 98.8 & $3 \cdot 4$ \\
\hline
\end{tabular}

$+\mathrm{Zn}, \mathrm{Zn}$-adequate; $-\mathrm{Zn}$, low-Zn; + Fe, Fe-supplemented; - Fe, unsupplemented.

$a+\mathrm{Zn}-\mathrm{Fe}>+\mathrm{Zn}+\mathrm{Fe}(P<0.05)$.

$b+\mathrm{Zn}-\mathrm{Fe}>-\mathrm{Zn}-\mathrm{Fe}(P<0.05)$. 
Table 6. Mean protein $(\mathrm{mg} / \mathrm{g}), \mathrm{DNA}(\mathrm{mg} / \mathrm{g})$, zinc $(\mu \mathrm{g} / \mathrm{g})$ and iron $(\mu \mathrm{g} / \mathrm{g})$ content of dried defatted fetuses on day 21 of pregnancy from groups of rats given diets varying in $Z n$ content, with or without Fe supplements

(Mean values with their standard errors)

\begin{tabular}{|c|c|c|c|c|c|c|c|c|c|}
\hline \multirow[b]{2}{*}{ Group } & \multirow[b]{2}{*}{$n$} & \multicolumn{2}{|c|}{ Protein } & \multicolumn{2}{|c|}{ DNA } & \multicolumn{2}{|c|}{$\mathrm{Zn}$} & \multicolumn{2}{|c|}{$\mathrm{Fe}$} \\
\hline & & Mean & SE & Mean & SE & Mean & SE & Mean & $\mathrm{SE}$ \\
\hline$+\mathrm{Zn}-\mathrm{Fe}$ & 10 & $831 \cdot 6$ & $28 \cdot 3$ & $22 \cdot 2$ & 0.7 & $161 \cdot 2^{a}$ & $4 \cdot 5$ & 297.8 & $20 \cdot 6$ \\
\hline$+\mathrm{Zn}+\mathrm{Fe}$ & 11 & $856 \cdot 5$ & $13 \cdot 7$ & $21 \cdot 3$ & 0.5 & $149 \cdot 4$ & $4 \cdot 0$ & $440 \cdot 1^{b}$ & $18 \cdot 7$ \\
\hline$-\mathrm{Zn}-\mathrm{Fe}$ & 14 & $847 \cdot 4$ & $14 \cdot 7$ & $21 \cdot 7$ & $0 \cdot 6$ & $130 \cdot 6$ & $2 \cdot 4$ & $292 \cdot 7$ & $20 \cdot 7$ \\
\hline$-\mathrm{Zn}+\mathrm{Fe}$ & 16 & $871 \cdot 2$ & 13.0 & $21 \cdot 5$ & 0.7 & $137 \cdot 3$ & $4 \cdot 1$ & $407 \cdot 4^{c}$ & $20 \cdot 4$ \\
\hline
\end{tabular}

$+\mathrm{Zn}$, Zn-adequate, $-\mathrm{Zn}$, low-Zn; $+\mathrm{Fe}$, Fe-supplemented; $-\mathrm{Fe}$, unsupplemented.

$a+\mathrm{Zn}-\mathrm{Fe}>-\mathrm{Zn}-\mathrm{Fe}(P<0.001)$.

$b+\mathrm{Zn}+\mathrm{Fe}>+\mathrm{Zn}-\mathrm{Fe}(P<0.01)$.

$c-\mathrm{Zn}+\mathrm{Fe}>-\mathrm{Zn}-\mathrm{Fe}(P<0.01)$.

and in the groups without $\mathrm{Fe}$ supplementation the addition of $\mathrm{Zn}$ significantly increased fetal wet weight $(P<0.05)$. It was noticed that the fetuses from the low- $\mathrm{Zn}$ mothers showed a higher incidence of morbidity than the others. In both low-Zn groups, $57 \%$ of mothers showed evidence of uterine and fetal haemorrhages. Brown patches were observed on the uterine wall in the region of the placenta; in the fetuses severe neck haemorrhages were noted. In the adequate- $\mathrm{Zn}$ groups, similar disturbances were observed in only $10 \%$ $(+\mathrm{Zn}-\mathrm{Fe})$ and $18 \%(+\mathrm{Zn}+\mathrm{Fe})$ of animals, and these were much less severe.

Results of protein and DNA analysis of the dried defatted fetuses are shown in Table 6 , together with the $\mathrm{Fe}$ and $\mathrm{Zn}$ contents. There were no differences in protein and DNA contents of the fetuses nor in the DNA:protein values. The addition of $\mathrm{Fe}$ to the diet increased fetal $\mathrm{Fe}$ in both the adequate- $\mathrm{Zn}(P<0.01)$ and low-Zn $(P<0.01)$ groups and there was no difference in the effect at the two $\mathrm{Zn}$ levels. The adequate- $\mathrm{Zn}$ mothers produced fetuses with a higher $\mathrm{Zn}$ concentration than those given a low- $\mathrm{Zn} \operatorname{diet}(P<0.001)$.

\section{DISCUSSION}

The suggestion has been made that, in humans, maternal tissue $\mathrm{Zn}$ depletion is associated with fetal growth retardation and that $\mathrm{Zn}$ deficiency may be exacerbated by the $\mathrm{Fe}$ supplements which are prescribed for many pregnant women (Meadows et al. 1981). It has been demonstrated that there is an interaction between $\mathrm{Fe}$ and $\mathrm{Zn}$ in the intestine such that as the $\mathrm{Fe}: \mathrm{Zn}$ value increases above $1, \mathrm{Zn}$ uptake is increasingly inhibited (Solomons \& Jacob, 1981). The $\mathrm{Fe}: \mathrm{Zn}$ value in an average diet is about 1 . However, it is usual practice for pregnant women to be given Fe supplements during pregnancy, such that their daily intake is increased about fourfold. Since their $\mathrm{Zn}$ intakes are unlikely to change much, the $\mathrm{Fe}: \mathrm{Zn}$ value will be greatly increased. In the present study we attempted to model the human situation by giving an Fe-supplemented diet to pregnant rats from day 1 of pregnancy onwards, such that the $\mathrm{Fe}: \mathrm{Zn}$ value in the adequate- $\mathrm{Zn}$ group was increased from 0.6 to 2.8 , and in the low-Zn groups from 5.2 to 24.9 . Typical commercial breeding diets for rats contain $30-35 \mathrm{mg} \mathrm{Fe} / \mathrm{kg}$; our semi-synthetic diet contained $35 \mathrm{mg} \mathrm{Fe} / \mathrm{kg}$. However, the maternal tibia and fibula and fetal Fe concentrations were significantly higher in the Fe-supplemented mothers, which suggests that the level of $35 \mathrm{mg} \mathrm{Fe} / \mathrm{kg}$ may not be optimal for pregnancy. The unsupplemented low- $\mathrm{Zn}$ group gained significantly less weight during 
the third trimester than both the low- $\mathrm{Zn} \mathrm{Fe}$-supplemented and the adequate- $\mathrm{Zn}$ groups, and this could be linked to the lower food intake of this group during this time period. There was a significant relationship between food intake and weight gain $(P<0.001)$ in each trimester, as might be expected. However, when the weight gain mean was adjusted to a common mean food intake to eliminate the effect of food intake, although the slope of regression was similar, the intercepts were different. Thus, differences in food intake did not account for all the differences in weight gain in the 3rd trimester.

The mechanism of $\mathrm{Zn}$ depletion of mothers in the UK suggested by Meadows et al. (1981) is likely to be dietary. $\mathrm{Zn}$, like $\mathrm{Fe}$, is only partially available for absorption by the body and its availability depends on many factors; for example, phytate (present in cereals and pulses) makes $\mathrm{Zn}$ less available from vegetables than from meat (O'Dell et al. 1972). There is, therefore, some concern about the adequacy of vegan or vegetarian diets for groups of the population with high requirements for $\mathrm{Zn}$, i.e. infants, growing children and pregnant women. There are difficulties in assessing $\mathrm{Zn}$ status, and measurement of $\mathrm{Zn}$ intake is of limited use without some idea of availability. Therefore, it is difficult to judge whether a dietary regimen is adequate for any particular group of people. However, one method of assessing $\mathrm{Zn}$ status that has been commonly used in animal studies is bone $\mathrm{Zn}$ (Williams \& Mills, 1970). We found no significant reduction in maternal bone $\mathrm{Zn}$ in mothers given a low-Zn diet, which agrees with findings by Hurley (1969) and suggests that bone acts as a long-term sink which is relatively unavailable in periods of acute stress, e.g. pregnancy. This makes the adequacy of dietary $\mathrm{Zn}$ during pregnancy an even more important factor, since there appears to be no substantial reserve of $\mathrm{Zn}$ for times when requirements exceed availability. Apgar (1968) also suggests that $\mathrm{Zn}$ stores are not available in amounts adequate for the stress of pregnancy and parturition.

Cunnane (1982) has demonstrated that $\mathrm{Zn}$-deficiency does not affect the duration of gestation and parturition. It was, therefore, quite valid to compare fetal weights on day 21 of pregnancy since fetuses from $\mathrm{Zn}$-deficient and control animals were of similar gestational age. Although there were no differences in numbers of fetuses, mean dry weight, protein, DNA or fat content, the mean wet fetal weight appeared to be affected by the $\mathrm{Zn}$ and $\mathrm{Fe}$ levels of the diet. In the adequate- $\mathrm{Zn}$ groups, the addition of Fe to the diet significantly reduced the fetal wet weight but not in the low-Zn groups. A separate effect of $\mathrm{Zn}$ was noted in the unsupplemented groups in that the wet weight was increased in mothers given an adequate- $\mathrm{Zn}$ diet compared with a low- $\mathrm{Zn}$ diet. The reduction in fetal wet weight with a low- $\mathrm{Zn}$ diet is not surprising, but the adverse effect on fetal wet weight of adding $\mathrm{Fe}$ in the adequate- $\mathrm{Zn}$ diet is not supported by any other variables, e.g. dry weight, $\mathrm{Zn}$ concentration, etc. It is clear from the results that the differences in wet weight, although significant at the $5 \%$ level, are small, and because there were no other differences in fetal composition, it would be premature to place much emphasis or indeed draw any firm conclusions from these observations.

It is not possible to comment on the effect of $\mathrm{Zn}$ deficiency on fetal survival at parturition because Caesarian section deliveries were carried out on day 21 of pregnancy. The severe fetal haemorrhaging observed in utero, however, suggests that parturition losses would have been greater in the low-Zn groups. This is supported by the evidence of other workers (Williams et al. 1973; Cunnane, 1982) who found an adverse effect of $\mathrm{Zn}$ deficiency on fetal survival at delivery. Indeed, both Apgar (1968) and Cunnane (1982) found that maternal $\mathrm{Zn}$ deficiency per se did not affect birth weight of the young but it significantly reduced survival rate.

There was a substantial fall in fetal $\mathrm{Zn}$ in both the low- $\mathrm{Zn}$ groups, but the Fe-supplemented group was no worse than the unsupplemented group. The addition of $\mathrm{Fe}$ to the adequate- $\mathrm{Zn}$ diet did not produce a significant reduction in fetal $\mathrm{Zn}$ concentration and it is therefore 
clear that the $\mathrm{Fe}$ supplements did not adversely affect $\mathrm{Zn}$ availability from the adequateor low- $\mathrm{Zn}$ diets. There was a much higher concentration of $\mathrm{Fe}$ in the fetuses of both Fe-supplemented groups, as was found in the bone measurements. The observation that there were insufficient mobilizable maternal $\mathrm{Zn}$ stores to maintain normal fetal $\mathrm{Zn}$ levels in animals given an adequate- $\mathrm{Zn}$ diet until conception but maintained on a low- $\mathrm{Zn}$ diet throughout pregnancy, has important implications. It emphasizes the necessity for adequate dietary $\mathrm{Zn}$ throughout pregnancy and points to the fact that the fetus depends mainly on dietary $\mathrm{Zn}$ for its supply rather than drawing on maternal stores. The addition of Fe to an adequate- or low- $\mathrm{Zn}$ diet at levels similar to those in human pregnancy does not have any major influence on the composition or size of the fetuses the day before term.

The authors would like to thank Mrs W. E. Nelson and Mrs J. Cooke for technical assistance, Mr M. Gee for AAS analyses, Mrs S. Ring for help with the BMDP computer program and $\mathrm{Mr}$ J. Franklin for his invaluable assistance with the statistical analysis.

\section{REFERENCES}

Anscombe, F. J. (1960). Technometrics 2, 123-147.

Apgar, J. (1968). American Journal of Physiology 215, 160-163.

Cunnane, S. C. (1982). British Journal of Nutrition 47, 495-504.

Hofert, J. F. \& White, A. (1968). Endocrinology 82, 767-775.

Hubbard, R. W., Matthew, W. T. \& Dubowic, D. A. (1970). Analytical Biochemistry 38, 190-201.

Hurley, L. S. (1969). American Journal of Clinical Nutrition 22, 1332-1339.

Lowry, O. H., Rosebrough, N. J., Farr, A. L. \& Randall, R. J. (1951). Journal of Biological Chemistry 193, 265-275.

Meadows, N. J., Ruse, W., Smith, M. F., Day, J., Keeling, P. W. N., Scopes, J. W., Thompson, R. P. H. \& Bloxam, D. L. (1981). Lancet ii, 1135-1137.

National Research Council (1974). Report of the Food and Nutrition Board, 8th ed. Washington DC: National Academy of Sciences.

O'Dell, B. L., Burpo, C. E. \& Savage, J. E. (1972). Journal of Nutrition 102, 653-660.

Siegel, S. (1956). Non-parametric Statistics for the Behavioural Sciences, p. 202. Kogakusha: McGraw Hill.

Snedecor, G. W. (1957a). Statistical Methods, 5th ed., p. 97. Iowa: Iowa State University Press.

Snedecor, G. W. (1957b). Statistical Methods, 5th ed., p. 287. Iowa: Iowa State University Press.

Solomons, N. W. \& Jacob, R. A. (1981). American Journal of Clinical Nutrition 34, 475-482.

University of California (1981). In BMDP Statistical Software [W. J. Dixon, editor]. London: University of California Press.

Widdowson, E. M. (1968). Biology of Gestation, vol. 2, pp. 1-49. New York: Academic Press.

Williams, R. B., Demertzis, P. \& Mills, C. F. (1973). Proceedings of the Nutrition Society 32, 3A-4A.

Williams, R. B. \& Mills, C. F. (1970), British Journal of Nutrition 24, 989-1003. 